\title{
Do airborne biogenic chemicals interact with the PI3K/Akt/mTOR cell signalling pathway to benefit human health and wellbeing in rural and coastal environments?
}

\author{
Michael N. Moore ${ }^{1,2,3,4}$ \\ ${ }^{1}$ European Centre for Environment \& Human Health (ECEHH), University of Exeter Medical School, \\ Knowledge Spa, Royal Cornwall Hospital, Truro, Cornwall TR1 3HD, UK \\ ${ }^{2}$ Department of Science and Innovative Technology (DSIT), University of Eastern Piedmont, Alessandria, \\ Italy \\ 3 Plymouth Marine Laboratory (PML), Prospect Place, The Hoe, Plymouth PL1 3DH, UK \\ ${ }^{4}$ School of Biological Sciences, University of Plymouth, Drake's Circus, Plymouth PL4 8DD, UK
}

\begin{abstract}
Living and taking recreation in rural and coastal environments promote health and wellbeing, although the causal factors involved are unclear. It has been proposed that such environments provide a counter to the stresses of everyday living, leading to enhanced mental and physical health. Living in natural environments will result in airborne exposure to a wide range of biogenic chemicals through inhalation and ingestion of airborne microbiota and particles. The "biogenics" hypothesis formulated here is that regular exposure to low concentrations of mixtures of natural compounds and toxins in natural environments confers pleiotropic health benefits by inhibiting the activities of interconnected cell signalling systems, particularly PI3K/Akt/mTORC1. When overactive, Akt and mTOR (mTORC1) can lead to many pathological processes including cancers, diabetes, inflammation, immunosuppression, and neurodegenerative diseases. There is a substantial body of evidence that many natural products (i.e., from bacteria, algae, fungi and higher plants) inhibit the activities of these protein kinases. Other mTOR-related interconnected metabolic control "switches" (e.g., PTEN \& NF$\mathrm{KB})$, autophagy and other cytoprotective processes are also affected by natural products.

The "biogenics" hypothesis formulated here is that regular intermittent exposure to a mixture of airborne biogenic compounds in natural environments confers pleiotropic health benefits by inhibiting activities of the highly interconnected PI3K/Akt/mTORC1 system. It is proposed that future experimental exposures to biogenic aerosols in animal models coupled with epidemiology, should target the activities of the various kinases in the PI3K/Akt/mTORC1 systems and related physiological processes for selected urban, rural and coastal populations in order to test this hypothesis.
\end{abstract}

Key words: autophagy, cell-signalling, green-blue space, mTOR, phytochemicals.

Corresponding author: Professor Michael N. Moore (mnm@pml.ac.uk) 


\section{INTRODUCTION}

Epidemiological evidence to support positive health benefits (biophilia - "green-blue space" effect) from living in and taking recreation in natural environments is mounting (Aspinall et al., 2015; Berman et al., 2008; Dadvand et al., 2005; Depledge et al., 2013; Maas et al., 2006; Park et al., 2007, 2010; Rook, 2013; Sandifer et al., 2015; SarrafZadegan \& AminiNik,1997; Wheeler et al., 2012; White et al., 2010, 2013; Wilson, 1984). Beneficial effects in wellbeing are especially prominent in individuals of lower socio-economic status (Maas et al., 2009; Mitchell \& Popham, 2008; Dadvand et al., 2012; Wheeler et al., 2012). The causative factors are unknown, although to date these beneficial effects have been attributed largely psychological mechanisms involving a reduction in stress through taking more exercise and living in aesthetically pleasing situations (White et al., 2014). However, psychological mechanisms are unlikely to explain the longer-lasting physiological health benefits, so other environmental factors may be involved, including low-level exposure to natural airborne microbiota and biogenic products (including phytochemical and particulate allergens) that are inhaled and ingested in rural and coastal areas (Christensen et al., 1999; Després et al., 2012; Jones \& Harrison, 2003; Matthias-Maser et al., 2000; Matsunaga et al., 2011; Ong et al., 1986, 1994; Paré \& Tumlinson, 1999; Postolache et al., 2007; Rook, 2013; Seedorf et al., 2014).

There is a growing body of evidence that inhalation and ingestion (i.e., via the upper respiratory tract mucus) of the airborne microbiota may be contributing to more effective immunoregulation (Cox et al., 2014; Rook, 2013; Seedorf et al., 2014; Smillie et al., 2011), while airborne biogenic chemicals are present in sufficient concentrations in aerosols, microbiota, spores and pollen to cause toxicity and allergic reactions (Artaxo \& Hansson, 1995; Bahadur et al., 2010; Bennett \& Klich, 2003; Christensen et al., 1999; D'amato, 2000; Gerssen et al., 2010; Graham et al., 2003; Lu et al., 2013; Dungan, 2011; Jones \& Harrison, 2004; Krivácsy et al., 2008; Kroll \& Seinfeld, 2008; Kulmala et al., 2001; MatthiasMaser et al., 2000; Paré \& Tumlinson, 1999; Pierce \& Henry, 2009; Rogge et al., 1993a, c; Russell et al., 2010; Skaug et al., 2001; Wang, 2008). Recently, Rook (2013) has presented a convincing argument that human exposure to microbiota and parasites ("old friends" hypothesis) contributes to improved immunoregulation and reduction in inflammation associated with many pathologies. This paper explores a complementary scenario to the psychological and immunoregulatatory explanations, based on exposure to bioactive biogenic compounds that can be found in these natural environments. A testable conceptual model is developed for the potential mechanisms of action of such biogenic products and how these mechanisms may relate to the observed health and wellbeing benefits.

\section{RATIONALE}

The sources of airborne environmental biogenic products in aerosols are widespread (see review by Després et al., 2012; and references for Table 1). These include volatile plant products (e.g., terpenoids), polyphenols (so called "antioxidants", e.g., anthocyanins, anthocyanidins, catechins, epicatechins, flavanols, flavanones, flavonoids, fulvic acids, humics, isoflavones, lignans, 
proanthocyanidins, procyanidins, stilbenes, tannins, etc.), isothiocyanates, carotenoids, allyl sulfides, pyrrolizidone alkaloids and other phytotoxins from plant and macroalgal fragments, pollen, lichen, fungi (and spores), and fern spores; antibiotics, phytochemicals, phytotoxins and viral proteins from airborne soil particle-associated viruses, bacteria, cyanobacteria, fungi and plant fragments; as well as algal, bacterial and cyanobacterial toxins in sea-surface microlayer/seawater aerosols (see references for Table 1; Bennick, 2002; Christensen et al., 1999; Cunliffe et al., 2013; Després et al., 2012; Fleming et al., 2005, 2007; Halliwell, 2009; Matsunaga et al., 2011; O'Dowd \& Leeuw, 2007; Pierce, 1986; Postolache et al., 2007; Rook, 2013; van Strien et al., 2004).

During the course of hominid evolution our ancestors will have been exposed to a legion of biogenic products through inhalation/ingestion and as part of the diet (Abrahams, 2002; Bennick, 2002; Christensen et al., 1999; Del Rio et al., 2013; Kennedy \& Wightman, 2011; Lippmann et al., 1980; Malloy \& Marr, 1997; Matricardi et al., 2000; Postolache et al., 2007; Rook, 2013; Skaug et al., 2001). Over the course of this longstanding exposure, adaptations will have occurred that facilitate tolerance of these often toxic compounds (Christensen et al., 1999; Del Rio et al., 2013; Postolache et al., 2007). Many of these compounds may actually facilitate human wellbeing; and removal of this exposure as a result of the relatively recent (in evolutionary terms) massive movement of human populations to urbanised environments may have contributed to a general decline in wellbeing. Could it be that rural and coastal environments are the norm for our species, as our ancestors frequently used coastal corridors for the global expansion of mankind Del Rio etal., 2013; Rook, 2013)?

Prominent among the biogenic phytochemical compounds of interest here are the so called polyphenolic antioxidants (Pandey \& Rizvi, 2009). These polyphenolic compounds are secondary metabolites of plants: they are often toxic at high concentrations, and have a defensive role in plants and plant pathology, where they act as natural pesticides against invading organisms (i.e., herbivores, nematodes, phytophagous insects, and fungal and bacterial pathogens; Beckman, 2000, Bennick, 2002; Paré \& Tumlinson, 1999). While most phytochemical uptake in humans is dietary from vegetables and fruit (Bennick, 2002; Carluccio et al., 2003; Del Rio et al., 2013; Kennedy \& Wightman), there is a large gap in our knowledge concerning alternative or complementary exposure routes for phytochemicals as discussed in this paper. Nonetheless, there is an extensive body of literature on the supposed health benefits of the consumption of phytochemicals, particularly polyphenolics (e.g., the "Mediterranean Diet"; Carluccio et al., 2003; Del Rio et al., 2013), with considerable interest being shown in these types of compounds by the pharmaceutical industry. Polyphenolics occur at a concentration around $2-3 \mathrm{mg} / \mathrm{g}$ in most fruits, such as grapes, apple, pear, cherries and berries; and a glass of red wine (e.g., contains among many others, the polyphenolic stilbenoid - resveratrol) or a cup of coffee, chocolate or tea will contain approximately $100 \mathrm{mg}$ of polyphenols (Del Rio et al., 2013; Pandey \& Rizvi, 2009). Dietary polyphenolics appear in the circulatory system as metabolites of Phase II biotransformation, and their plasma concentration rarely exceeds nM concentrations, indicating that they can be bioactive at very low levels (Del Rio et al., 2013; Kennedy \& Wightman, 2011). However, while the weight of evidence indicates that many 
ingested polyphenols are beneficial for health, some airborne polyphenols can be harmful such as tannins causing byssinosis or "brown lung disease" (Bennick, 2002, Del Rio et al., 2013; Kennedy \& Wightman, 2011; Pandey \& Rizvi, 2009).

Volatile phytochemicals (volatile organic chemicals - VOCs) such as terpenoids have also been implicated in beneficial roles in human health, with some having anti-cancer properties (Chen et al., 2014; Kusuhara et al., 2012; Matsunaga et al., 2011; Park et al., 2010b; Son et al., 2013). A number of terpenoids inhibit NF-KB signalling reducing inflammation and inhibit mTOR and activating autophagy (Cock, 2013; Russo et al., 2014; Salminen et al., 2008). The Japanese practice of "Forest Bathing" or Shinrin-yoku has been shown to have significant health benefits including a reduction in cortisol, which can be a consequence of mTOR inhibition (De Martino et al., 2012; Park et al., 2007, 2010a). Taking recreation in forests, as in Shinrin-yoku, will result in exposure to airborne VOCs including compounds such as $\alpha$-pinene, $\beta$-pinene, d-limonene, camphene, and $\alpha$-terpinene, all of which can have health benefits (Cock, 2013; Russo et al., 2014; Son et al., 2013).

Many of the biogenic compounds that will be discussed in this paper are toxic at higher concentrations, although generally the concentrations encountered from airborne sources will be significantly below the toxic threshold (Després et al., 2012). This raises the issue of whether any physiological responses reactions to these compounds will constitute a hormetic effect (Afanas'ev, 2010; Blagosklonny, 2011; Duke, 2011; Hooper et al., 2010; Menendez et al., 2013). Hormesis is discussed in a later section, and refers to a biphasic dose response to an environmental agent characterized by low dose stimulation or beneficial effect and a high dose inhibitory or toxic effect (Mattson, 2008).

The hypothesis developed here is that airborne biogenic compounds in rural and coastal environments interact with specific cell signalling pathways to exert beneficial effects that parallel the effects of caloric restriction (CR), by targeting the PI3K/AktT/mTORC1 (PI3K - phosphatidylinositol-3 kinase, Akt - serine/threonine kinase or protein kinase B - PKB, and mTORC1 - mechanis c target of rapamycin complex 1 ), NF-KB (nuclear factor kappa-light-chain-enhancer of activated B cells) and PTEN (phosphatase and tensin homolog, tumour suppressor) pathways and autophagy (Fig. 1; for a detailed schematic of mTOR-linked cell signalling pathways - see the review by Laplante \& Sabatini, 2009; Zhang et al., 2012). Inhibition of these pathways, with the exception of PTEN can result in antiinflammatory, cardiovascular, anti-diabetes, neurological, anti-psychotic and anti-cancer health benefits (Afanas'ev, 2010; Arafa et al., 2011; Asnaghi et al., 2010; Balistreri et al., 2013; Ballou \& Lin, 2008; Bassères \& Baldwin, 2006; Beevers et al., 2013; Blagosklonny, 2011; Corradetti \& Guan, 2006; Dan et al., 2008; de Souza et al., 2010; Deeb et al., 2007; Harries et al., 2012; Hau et al., 2013; Johnson et al., 2009; Lamming et al., 2013; Laplante \& Sabatini, 2010, 2012, 2013; Lee et al., 2013; Madrid et al., 2001; Markman et al., 2010; Martin et al., 2012; Sabatini, 2006; Salminen \& Kaarniranta, 2009a, c; Steelman et al., 2011; Tan et al., 2014; Trocoli \& Djavaheri-Mergny, 2011; von Roemeling et al., 2013; Wang et al., 2009; Weijenberg et al., 2013; Xie et al., 2013; Zhang et al., 2012; Zhang et al., 2011; Zhou et al., 2010). 


\section{INHALATION AND INGESTION OF NATURAL PRODUCTS}

\subsection{Biogenic products in the natural environment}

The air that we breath contains a plethora of particles including viruses, microbes, fungi, soil and plant materials that will associate with the mucus membranes in our upper respiratory system and be ingested (see Table 1 references and Abrahams, 2002; Després et al., 2012; Jones \& Harrison, 2003; Lippmann et al., 1980; Rook, 2014; Tsunetsugu et al., 2010; Williams, 1963; Womiloju et al., 2003). The diversity of this exposure is much greater in the natural environment than in the urban built environment (Fischer \& Dott, 2003; Frohlich-Nowoisky 2009; Frumkin, 2001; Malloy \& Marr, 1997; Matricardi et al., 2000; Okuda et al., 2005; Rook, 2013; Womiloju, 2014).

Bacteria, cyanobacteria, unicellular algae and macroalgae, plants and fungi all produce a wide variety of biogenic products, many of which interact with biological systems (see Table 1). These include antibiotics, microcystins, nodularins, polyphenols, algal toxins, mycotoxins, alkaloids and volatile products, many of which can readily become airborne (Table 1). Some of these products are present in airborne plant and macroalgal fragments, spores (bacteria, fungi and ferns), pollen grains and associated with airborne soil particles. In coastal environments airborne nano- and micro-droplets of seawater can carry algal, macroalgal (in fragments), cyanobacterial and bacterial products inland for considerable distances (Table 1; Clarke \& Zika, 2000; Cunliffe et al., 2013; Després et al., 2012; Fleming et al., 2005, 2007; O'Dowd \& Leeuw, 2007; Pierce, 1986; Pierce \& Henry, 2008; Wang, 2008).

\subsection{Biogenic and anthropogenic products in the built environment}

The diversity and types of microbiota and fungi in the built environment is very different from the natural environment, and is dominated by micrococcus species (Rook, 2013; Shelton et al., 2002). Consequently, human exposure to the airborne microbes, spores and biogenic products in the built environment will be likewise dissimilar to those in the natural environment. Built environments also contain many synthetic and airborne combustion products (Pott \& Stobert, 1983). The synthetic contaminants will be derived from the treatment of building materials with biocides and various surface treatments and fire retardents in soft furnishings and carpets (Reemtsma et al., 2008). Combustion products will include polycyclic aromatic hydrocarbons, and nitrogen, oxygen and sulphur heterocyclics derived from a range of industrial and domestic combustion processes, as well as airborne urban road-tyre dust (Pott \& Stobert, 1983; Rogge et al., 1993a, c).

\section{CELLULAR TARGETS FOR BIOGENIC PRODUCTS}


As indicated in the preceding section, humans are subjected to a highly diverse array of natural products derived from the microbiota, fungi and plants; and also, man-made (anthropogenic) chemical contaminants particularly in the urban environment (Table 1; Pott F, Stobert, 1983; Rogge et al., 1993a, b). There is a huge scientific literature on the interactive and harmful effects of airborne pollutants but rather less on the interactions and health effects of naturally occurring biogenic products (Brunekreef \& Forsberg, 2005; Del Rio et al., 2013; Rogge et al., 1993a, c).

\subsection{Interactions with cell signalling pathways (Fig. 1)}

\subsubsection{PI3K-Akt-mTOR}

Surprisingly, many of the airborne biogenic products that have been identified in the natural environment interact with some of the key components of the cell signalling network in humans and all other eukaryotic organisms (Fig. 1; Table 1). These components include the functional molecules of the phosphatidylinositol 3'-kinase-Akt-mammalian target of rapamycin (PI3K-Akt-mTOR) pathway (Fig. 1), which is strongly implicated in the control of cellular growth (see overviews by Afanas'ev, 2010; Asnaghi et al., 2010; Corradetti \& Guan, 2006; Farrand et al., 2014; Laplante \& Sabatini, 2012; Markman et al., 2010; Martin et al., 2012). This pathway is strongly linked to regulation of growth, protein synthesis, autophagy, cortisol concentration, innate immunity, inflammation, neurodegeneration, T cell regulation (Treg), and the growth of many cancers, as well as the inhibition of uptake of iodine (De Martino et al., 2012; de Souza et al., 2010; Gerriets \& Rathmell, 2012).

The mammalian target of rapamycin (mTOR) is a serine/threonine kinase that controls many aspects of cellular physiology, including transcription, translation, cell size, cytoskeletal organization and autophagy (see reviews by Laplante \& Sabatini, 2009, 2012). Recent advances in the mTOR signalling field have found that mTOR exists in two heteromeric complexes, mTORC1 and mTORC2. The activity of mTORC1 is regulated by the integration of many signals, including growth factors, insulin, nutrients, exercise, energy availability, vitamin $D$ and cellular stressors such as hypoxia, osmotic stress, reactive oxygen species (ROS) and viral infection (Dreyer et al., 2006; Laplante \& Sabatini, 2009, 2012; Lisse \& Hewison, 2011; Martin et al., 2012). Recent advances in the mTOR signalling field have clarified how the two mTOR complexes are regulated (Laplante \& Sabatini, 2009).

The PI3K/Akt/mTORC1 pathway is an intracellular signalling pathway important in regulating cell growth, apoptosis (Type 1 programmed cell death) and longevity, which when overactive can lead to many pathological processes including cancers, diabetes, inflammation, immunosuppression, and neurodegenerative diseases (Fig. 1; Laplante \& Sabatini, 2012). PI3K activation in turn activates Akt, which activates mTOR, and in many cancers, this pathway is overactive, thus reducing apoptosis and allowing proliferation of abnormal cells (Dan et al., 2008; Laplante \& Sabatini, 2009, 2012). Consequently, some experimental cancer drugs aim to inhibit the signalling sequence at some point (e.g., metformin and Torisel; von Roemeling et al., 2013). The PI3K pathway may also be overactive 
because PTEN (tumour suppressor) is faulty or deficient (Corradetti \& Guan, 2006; Steelman et al., 2011).

mTOR (mTORC1) is also a nutrient and stress sensor and when active suppresses the process of lysosomal autophagy which is crucial for the effective turnover of cellular proteins and organelles (Fig. 1; Laplante \& Sabatini, 2012). Low nutrient levels and other environmental stressors (e.g., hypoxia, execise), including many phytochemicals, switch mTORC1 off, hence activating autophagy (Cuervo, 2004; Kim et al., 2012; Levine \& Kroemer, 2008, Klionsky et al., 2007; Moore et al., 2007; Nacarelli et al., 2014; Zhang et al., 2012). Autophagy is important in removing oxidatively damaged and defective proteins and organelles, and is strongly linked with longevity and protection against tumours (Cuervo, 2004; Kim et al., 2012; Levine \& Kroemer, 2008; Martins et al., 2011; Moore, 2008; Moore et al., 2008; Rubinsztein et al., 2011; Salminen \& Kaarniranta, 2009a; Zhang et al., 2012).

\subsubsection{PTEN and NF-KB}

PTEN is a tumor suppressor protein, which is mediated via its phosphatase action. This phosphatase acts as part of a chemical pathway that signals cells to stop dividing and can cause cells to undergo Type 1 programmed cell death (apoptosis) when necessary. These functions prevent uncontrolled cell growth that can lead to the formation of tumors (Fig. 1; Steelman et al., 2011). The polyphenol resveratrol induces the expression of antioxidant enzymes such as catalase (Cat) and manganese superoxide dismutase (MnSOD), at nutritionally relevant concentrations, through a mechanism involving the PTEN/Akt signaling pathway (Inglés et al., 2014). Conversely, NF-KB is considered to play key roles in the development and progression of many cancers, the mechanisms whereby this transcription factor is activated in cancer are poorly understood (Fig. 1; Balistreri et al., 2013; Bassères \& Baldwin, 2006; Madrid et al., 2001; Salminen \& Kaarniranta, 2009b, 2010; Trocoli \& Djavaheri-Mergny, 2011; Wang et al., 2009). The serine-threonine kinase Akt is also a key oncoprotein in a variety of cancers, which can be activated by mutations in PI3K, loss of expression/activity of PTEN, or through signalling induced by growth factors and their receptors (Arafa et al., 2011). A key effector of Akt-induced signaling is the regulatory protein mTOR (see above). mTOR downstream from Akt controls NF-KB activity in PTEN-null/inactive cancer cells via interaction with IKK (inhibitor of nuclear factor kappa-B kinase), and stimulation and regulation of autophagy in the context of ageing processes (Dan et al., 2008; Rubinsztein et al., 2011; Salminen et al., 2012).

Given the key anti-apoptotic functions ascribed to NF-kB (see Basserès \& Baldwin 2006), it is likely that NF-KB activation downstream from Akt functions to promote cell survival. Previous evidence for this was provided by Madrid et al. (2001). This may indicate that Akt, at least in the setting of loss of PTEN function, promotes IKK-dependent activation of NF-KB via mTOR and Raptor, which controls the expression of certain key anti-apoptotic genes. In this pathway, TORC1 would promote cell survival through a mechanism that is independent of the traditional translational-dependent pathways associated with mTOR activity (Dan et al., 2008). 


\subsection{Autophagy, anti-ageing \& possible hormetic-type effects}

Inhibition of mTOR activates autophagy: a cellular physiological mechanism for cellular repair (cytoprotection) through the removal of damaged proteins, protein aggregates (e.g., in neurodegenerative diseases) and damaged or redundant organelles such as mitochondria (Fig. 2; Cuervo, 2004; Eskelinen et al., 2009; Mizushima et al., 2008). Consequently, the autophagic processes have been increasingly shown to have protective functions against ageing and many diseases including cancers, neurodegenerative diseases (Fig. 2; Cuervo, 2004; Ferrari et al., 2011; Hippert et al., 2006; Mizushima et al., 2008; Ozkan et al., 2015; Rubinsztein et al., 2011; Salminen \& Kaarniranta, 2009a; Selvakumaran et al., 2013; Trocoli \& Djavaheri-Mergny, 2011; Zhang et al., 2012). Autophagic lysosomal digestion is triggered by many environmental stressors including caloric restriction (CR), hypoxia, ROS, exercise, many toxins and phytochemicals, and sunlight and vitamin D mediated via the vitamin D receptor - VDR (Chatterjee etal., 2014; Delmas et al., 2011; Ferrari et al., 2011; Mestre \& Columbo, 2013; Moore et al., 2008; Wu \& Sun, 2011; Zhang et al., 2012).

Autophagy, triggered by inhibition of mTOR and other mTOR-independent pathways (e.g., SIRT 1 and VDR), is probably an important component of hormetic responses, particularly in anti-ageing processes (Blagosklonny, 2011, Kim et al., 2012; Martins et al., 2011; Moore \& Stebbing, 1976; Rubinsztein et al., 2011; Salminen et al., 2012; Wu \& Sun, 2011). mTOR (mTORC1) is also a nutrient and stress sensor that regulates lysosomal autophagy, apoptosis (Type 1 programmed cell death PCD 1) and senescence, that when inhibited can have beneficial consequences as indicated above. In essence, many of the natural biogenic compounds described in this paper may act as calorie restriction (CR) mimetics: $C R$ is well known to have beneficial effects in a wide range of organisms by increasing lifespan and reducing the risk from age-related cancers, cardiovascular and neurodegenerative diseases (Mattson \& Wan, 2005; Fontana et al., 2010).

Cells use autophagy and the ubiquitin-proteasome system as their major protein degradation pathways (Cuervo, 2004; Klionsky et al., 2007; Kraft et al., 2010; Lamb et al., 2013). While the ubiquitin-proteasome system is involved in the rapid degradation of proteins, autophagy pathways can selectively remove protein aggregates and damaged or excess organelles. Although autophagy has long been viewed as a fairly random cytoplasmic degradation system, the involvement of ubiquitin as a specificity factor for selective autophagy is rapidly emerging (Kraft et al., 2010). Recent evidence also suggests strong interactions (crosstalk) between proteasome-mediated degradation and selective autophagy (Kraft et al., 2010).

Low-dose exposures to some phytochemicals can trigger a cellular stress response and subsequently induce adaptive stress resistance known as hormesis (Blagosklonny, 2011; Duke, 2011; Martins et al., 2011; Mattson, 2008). Stress resistance involves a number of molecular adaptations including activation of AMP kinase, autophagy, and alterations cell survival and longevity genes (Fig. 2). Salminen and Kaarniranta (2010) have proposed that anti-inflammatory and anti-cancer responses induced by phytochemicals are caused by phytohormetic stress resistance involving the suppression 
of NF-KB. The NF-KB system is a pleiotropic regulator that has opposing effects, both detrimental and beneficial (biphasic) responses (Salminen \& Kaarniranta, 2010; Trocoli \& Djavaheri-Mergny, 2011). Its major function is maintaining innate immunity and protection against apoptosis as a result of tissue damage. Autophagy is involved in several cellular functions regulated by NF-KB including cell survival, differentiation, senescence, inflammation, and immunity. On a molecular level, autophagy and NF-KB share common upstream signals and regulators and can control each other through positive or negative feedback loops, thus ensuring homeostatic responses.

If the hypothesis developed in this paper receives future support from epidemiological data, and airborne biogenic agents are tagetting key components of cell signalling such as mTOR, then any accruing health benefits are like to involve cytoprotective processes such as autophagy in counteracting cellular processes leading to disease and ageing. Exposure to sunlight (UV radiation) and generation of vitamin $D$ in rural and coastal populations in comparison to urban populations is also likely to contribute to beneficial enhanced autophagy (Lisse \& Hewison, 2012; Wu \& Sun, 2011). Extending this argument further: we can speculate that we would expect to see a reduction in vitamin D induced autophagy in more northerly latitudes (Northern Hemisphere) with a corresponding reduction in human health as has been observed (see review by Pearce \& Cheetham, 2010).

\subsection{Viruses and viral fragments}

Viruses and viral fragments will comprise part of the natural particulate component of airborne material inhaled and ingested in both rural and coastal settings (Verrault et al., 2008; Whon et al., 2012).

A considerable portion of the dissolved organic carbon (DOC) content of seawater is composed of viral material (Griffen et al., 2003; Steward et al., 2013; Wilhelm \& Suttle, 1999; Williamson et al., 2008). Much of this viral content is phage material that infects marine phytoplankton but will also include pathogens from sewage and farmland runoff and marine snow (Shapiro et al., 2014).

Replication of mammalian DNA viruses requires that they gain control of key cellular signalling pathways that affect broad aspects of cellular macromolecular synthesis, metabolism, growth and survival (Krajcsi \& Wold, 1998). The PI3K-Akt-mTOR pathway is one such pathway; and DNA viruses have evolved various mechanisms to activate this pathway in order to obtain the benefits of Akt activation, including the maintenance of translation through the activation of mTOR (Buchkovich et al., 2008; Krajcsi \& Wold, 1998). However, viruses must overcome the inhibition of this pathway that results from the activation of cellular stress responses during viral infection, although multiple mechanisms have evolved to circumvent inhibitory stress signalling.

\section{SUMMARY \& CONCLUSIONS}


Many airborne bioactive biogenic chemicals produced by plants, algae, fungi and bacteria are inhaled/ingested by the human populations of rural and coastal areas (Table 1). The concentrations of these chemicals will be low; however, fairly continuous exposure to a diversity of bioactive chemicals may be responsible for inhibition of the mTORC1 component of the PI3K/Akt/mTOR cell signalling pathway. Such a reduction in the activity of the mTOR pathway will probably confer pleiotropic health benefits (Fig. 3; Laplante \& Sabatini, 2012).

Ensuing benefits will include a reduction in inflammatory processes that can contribute to cardiovascular disease, neurodegenerative diseases, depression and age-related cancers (Fig. 3). Additional benefits may involve activation of the so-called sirtuin longevity genes (Salminen \& Kaarniranta, 2009a). If empirical measurements of the mTOR pathway and other related signalling processes support the hypothesis developed in this paper, then it may be possible to mimic some of the health benefits of living close to the natural environment.

Cytoprotective autophagy is likely to be a key player in any health benefits resulting from interactions with phytochemicals and other products that trigger the signalling pathways for this process. Currently there are a number of drugs in everyday use, such as aspirin (a polyphenol), metformin, and Torisel that are inhibitors of mTOR and inducers of autophagy (Fig. 1; Ferrari et al., 2011; Zhang et al., 2011; Zhou et al., 2010). These compounds are termed rapologues because they mimic the mTOR inhibitor rapamycin; and considerable interest in mTOR inhibitors is being exhibited by the pharmaceutical industry in the quest for caloric-restriction (CR) mimetic drugs (Davinelli et al., 2012; de Magalhães et al., 2011).

It is highly probable that modulation of cell signalling (if confirmed) of the type described above is only one of a number of potentially interactive factors involved in the observed health benefits, including psychological effects, execise, more effective immunoregulation, vitamin D and exposure to sunlight, as well as dietary uptake of bioactive phytochemicals (Cox et al., 2014; Del Rio et al., 2013; Depledge et al., 2013; Lisse \& Hewison, 2011; Maas et al., 2006; Pandey \& Rizvi, 2009; Pearce \& Cheetham, 2010; Rook, 2013; Seedorf et al., 2014; Smillie et al., 2011; Wheeler et al., 2012; White et al., 2010, 2013; Wu \& Sun, 2011). Figure 3 shows a comparison of the potential explanatory capacity of each of the three hypotheses in the context of observable health benefits from exposure to green-blue space.

There is evidence that many dietary biogenic compounds, particularly polyphenols, exert their biological effects through synergistic interactions (Kennedy \& Wightman, 2011). Other cell signalling components, not discussed in this paper, are targetted as well by dietary polyphenols, including MAPK/ERK (related to cancer), COX-2, AMPK, etc. so these will also need to be considered in the context of airborne phytochemicals (Del Rio et al, 2013; Khan et al., 2006; Rahman et al., 2006; Ramos, 2008).

Finally, does living in the modern built environment constitute a significant change of airborne milieu for humans; and should the natural environment be considered "the norm", as this is what hominids and hominins, and specifically humans, have been exposed to for most of their evolution? 
Consequently, is the increase in wellbeing observed in the natural environment an improvement or should it be considered as the baseline state? In the urban environment there will be a deprivation of airborne exposure to a considerable diversity of biogenics mostly targetting the PI3K/Akt/mTOR cell signalling pathway; and often an increase in exposure to man-made contaminant xenobiotics. A crucial question for future research is whether the concentration of bioactive chemicals in natural aerosols is sufficient to interact effectively with cell signalling, in the manner hypothesised in this paper. Certainly airborne phytochemical allergens can interact with cell signalling systems to elicit a hypersensitive reaction from the immune system (Laiidi et al., 2003; Postolache et al., 2007). Consequently, future characterisation of the cell signalling related bioactivity of phytochemicals and other biogenic compounds in natural aerosols will be critical in determining the validity of this "biogenics" hypothesis, as has already the case with airborne marine algal toxins (Cheng et al., 2005a, b, 2007).

\section{PROSPECTUS}

Based on the discussion in this paper, it is proposed that future epidemiological investigations on the health benefits of natural environments should target the activities of the various kinases in the $\mathrm{PI}$ IK/AKT/mTORC1 systems and biomarkers of autophagy for selected urban, rural and coastal populations in order to test this "biogenics" hypothesis. This type of data probably already exists in some epidemiological databases (Harries et al., 2012), but has not yet been tested in the context of the question posed in this paper.

Experimental and observational testing of the "biogenics" hypothesis will be required to complement any supporting epidemiological data that may emerge. A suggested way forward is as follows:

- detailed seasonal sampling and analysis to characterise airborne biogenic compounds is needed both from urban and rural/coastal environments at various latitudes

- determination of bioactivity of the airborne biogenics identified will need to be confirmed in laboratory animal tests involving exposure to phytochemical aerosols

- testing for endpoints associated with the PI3K/Akt/mTOR systems and PTEN, as well as biomarkers for autophagy (e.g, Atg proteins - Lamb et al., 2013), apoptosis, inflammation, oxidatively damaged proteins (e.g., protein carbonyls and aggregates, ceroid lipofuscin), and higher level health indicators

- transcriptomic, proteomic and epigenomic studies in experimental animals in order to develop a framework of mechanistic understanding of molecular and cellular action of biogenic chemicals 
- pre-clinical tests conducted in human volunteers with endpoints selected on the basis of the results from animal exposures.

Finally, if this hypothesis is supported by the data, then public health strategists and urban planners will need to take it into consideration for the improvement of the health and wellbeing of urban dwellers. Essentially, is it possible to effectively "bottle" the benefits of natural green-blue space? Perhaps this could be facilitated by adding natural phytochemicals to aerosols in the home, and in large public spaces such as shopping malls, theatres and cinemas. Also, the role of exercise (an inhibitor of mTORC1 by increasing the activity of AMPK - see Fig. 1) needs to be considered as an interacting factor, as this will increase respiration and, hence, inhaled and ingested airborne biogenics (Dreyer et al., 2006). Currently, there is very extensive consideration of the health-related properties of bioactive phytochemicals in the diet; and supplementing these in foodstuffs may provide an alternative route to attain the health benefits discussed above (Del Rio et al., 2013; Kennedy \& Wightman, 2011; Khan et al., 2006; Kim et al., 2013; Rahman et al., 2006; Ramos, 2008).

Acknowledgements: This study was supported in part by funding from a Research Fellowship awarded by the Department of Science and Innovative Technology (DSIT), University of Eastern Piedmont, Alessandria, Italy; and "in kind" support from the European Centre for Environment and Human Health (ECEHH, University of Exeter Medical School, Truro, UK), and a Plymouth Marine Laboratory (PML) Fellowship (PML, Plymouth, UK). The author is very grateful to Prof. Graham Rook (UCL, London, UK), Prof. Lora Fleming (ECEHH, U. Exeter Medical School), Dr Mat White (ECEHH, U. Exeter Medical School), Prof. Mike Depledge (ECEHH, U. Exeter Medical School), Prof. Lorna Harries (U. Exeter Medical School) and Prof. Aldo Viarengo (DSIT, U. Eastern Piedmont, Amadeo Avogaddro, Italy) for critically reading this paper and making many helpful recommendations. The author is not aware of any conflicts of interest. 


\section{References}

Abrahams PW 2002. Soils: their implications to human health. Sci. Total Environ. 291: 1-32

Afanas'ev I 2010. Signaling and damaging functions of free radicals in aging - free radical theory, hormesis, and TOR. Aging \& Disease 1: 75-88

Al-awar RS, Corbett TH, Ray JE, Polin L, Kennedy JH, Wagner MM, Williams DC 2004. Biological evaluation of cryptophycin 52 fragment $A$ analogues: effect of multidrug resistance ATP binding cassette transporters on antitumor activity. Mol. Cancer Ther. 3: 1061-1067

Allen KJ, Koplin JJ, Ponsonby AL, Gurrin LC, Wake M, Vuillermin P, Martin P, Dharmage SC 2013. Vitamin D insufficiency is associated with challenge-proven food allergy in infants. Journal of allergy and clinical immunology, 131: 1109-1116

Arafa El-S, Zhu Q, Shah ZI, Wani G, Barakat BM, Racoma I, El-Mahdy MA, Wani AA 2011. Thymoquinione up-regulates PTEN expression and induces apoptosis in doxorubicin-resistant human breast cancer cells. Mutat. Res. 706: 28-35

Artaxo, P, Hansson H-C 1995. Size distribution of biogenic aerosol particles from the Amazon Basin. Atmos. Environ. 29: 393-402

Asnaghi L, Bruno P, Pruiulla M, Nicolin A 2004. mTOR: a protein kinase switching between life and death. Pharmacol. Res. 50: 545-549

Aspinall P, Mavros P, Coyne R, Roe J 2015. The urban brain: analysing outdoor physical activity with mobile EEG. Br. J. Sports Med. 49: 272-276

Badadani, M 2012. Autophagy mechanism, regulation, functions and disorders. ISRN Cell Biology 2012: Article ID 927064, 11 pages http://dx.doi.org/ 10.5402/2012/ 927064

Bahadur R, Uplinger T, Russell LM, Sive BC, Cliff SS, Millet DB, Goldstein A, Bates T S 2010. Phenol groups in northeastern US submicrometer aerosol particles produced from seawater sources. Environ. Sci. Technol. 44: 2542-2548

Balistreri CR, Candore G, Accardi G, Colonna-Romano G, Lio D 2013. NF-kB pathway activators as potential ageing biomarkers: targets for new therapeutic strategies. Immun. Ageing 10:24. doi: 10.1186/1742-4933-10-24

Ballou LM, Lin RZ 2008. Rapamycin and mTOR kinase inhibitors. J. Chem. Biol. 1: 27-36

Banerjee J, Biswas S, Madhu NR, Karmakar SR, Biswas SJ 2014. A better understanding of pharmacological activities and uses of phytochemicals of Lycopodium clavatum: a review. J. Pharmacognosy Phytochem. 3: 207-210

BassèresDS, Baldwin AS 2006. Nuclear factor-kappaB and inhibitor of kappaB kinase pathways in oncogenic initiation and progression. Oncogene 25: 6817-30 
Beckman $\mathrm{CH}$ 2000. Phenolic-storing cells: keys to programmed cell death and periderm formation in wilt disease resistance and in general defence responses in plants? Physiol. Mol. Plant Pathol. 57: $101-110$

Beevers CS, Zhou H, Huang S 2013. Hitting the golden TORget: curcumins's effects on mTOR signaling. Anticancer Agents Med. Chem. 13: 988-994

Bennick A 2002. Interaction of plant polyphenols with salivary proteins. Crit Rev Oral Biol Med 13:184-196

Bennett, JW, Klich MA 2003. Mycotoxins. Clin. Microbiol. Rev. 16: 497-516

Berman MG, Jonides J, Kaplan S 2008 The cognitive benefits of interacting with nature. Psychol Sci 19: $1207-1212$

Bharate SB, Sawant SD, Pal Singh P, Vishwakarma RA 2013. Kinase inhibitors of marine origin. Chem. Rev. 113: 6761-6815

BharateSB, Yadav RR, Battula S, Vishwakarma RA 2012. Meridianins: marine-derived potent kinase inhibitors. Mini Rev. Med. Chem. 12: 618-631

Blagosklonny MV 2011. Hormesis does not make sense except in the light of TOR-driven aging. Aging 3: 1051-1062

Bode AM, Dong Z 2013. Signal transduction and molecular targets of selected flavonoids. Antioxid. Redox Signaling 19: 163-180

Boopathy NS, Kathiresan K 2010. Anticancer drugs from marine flora: an overview. J. Oncol. 2010, Article ID 214186, 18 pages, 2010. doi:10.1155/2010/214186

Brunekreef B, Forsberg B 2005. Epidemiological evidence of effects of coarse airborne particles on health. Eur. Respir. J. 26: 309-318

Buchkovich NJ, Yu Y, Zampieri CA, Alwine JC 2008. The TORrid affairs of viruses: effects of mammalian DNA viruses on the PI3K-Akt-mTOR signalling pathway. Nat. Rev. Microbiol. 6: 266275

Campos MGR, Bogdanov S, de Almeida-Muradian LB, Szczesna T, Mancebo Y, Frigerio C, Ferreira F 2008. Pollen composition and standardisation of analytical methods. J. Apicult. Res. Bee World 47: 156-163

Carluccio MA, Siculella L Ancora MA, MassaroM, Scoditti E, Storelli C, Visioli F, Distante A, De Caterina R 2003. Olive oil and red wine antioxidant polyphenols inhibit endothelial activation antiatherogenic properties of mediterranean diet phytochemicals. Arterioscler. Thromb.Vasc. Biol. 23: 622-629

Chai T-T, Panirchellvum E, Ong H-C, Wong F-C 2012. Phenolic contents and antioxidant properties of Stenochlaena palustris, an edible medicinal fern. Bot. Studies 53: 439-446 
Chatterjee S, Sarkar S, Bhattacharya S 2014. Toxic metals and autophagy. Chem. Res. Toxicol., 27: $1887-1900$

Chen WQ, Xu B, Mao JW, Wei FX, Li M, Liu T, Xiao-Bao J, Zhang LR 2014. Inhibitory effects of apinene on hepatoma carcinoma cell proliferation. Asian Pacific J. Cancer Prev. 15: 3293-3297

Cheng YS, McDonald JD, Kracko D, Irvin CM, Zhou Y, Pierce RH, Henry MS, Bourdelaisa A, Naar J, Baden DG 2005a. Concentration and particle size of airborne toxic algae (Brevetoxin) derived from ocean red tide events. Environ. Sci. Technol. 39: 3443-3449

Cheng YS, Zhou Y, Irvin CM, Pierce RH, Naar J, Backer LC, Fleming LE, Kirkpatrick B, Baden DG 2005b. Characterization of marine aerosol for assessment of human exposure to brevetoxins. Environ. Health Perspect.113: 638-643

Cheng YS, Zhou Y, Irvin CM, Kirkpatrick B, Backer LC 2007. Characterization of aerosols containing microcystin. Mar. Drugs 5: 136-150

Christensen LP, Jakobsen HB, Paulsen E, Hodal L, Andersen KE 1999. Airborne Compositae dermatitis: monoterpenes and no parthenolide are released from flowering Tanacetum parthenium (feverfew) plants. Arch. Dermatol. Res. 291: 425-431

Clark CD, Zika RG 2000. Marine organic photochemistry: from the sea surface to marine aerosols. In Marine chemistry - The Handbook of Environmental Chemistry Volume 5D, pp. 1-33. Springer Berlin Heidelberg

Cock IE 2013. The phytochemistry and chemotherapeutic potential of Tasmannia lanceolata (Tasmanian pepper): a review. Pharmacog. Comm. 3: 1-13

Corradetti MN, Guan K-L 2006. Upstream of the mammalian target of rapamycin: do all roads pass through mTOR. Oncogene 25: 6347-6360

Cox LM, Yamanishi S, Sohn J, Alekseyenko AV, Leung JM, Cho I, Kim SG, Gao Z, Mahana, D, Rodriguez JGZ, Rogers AB, Robine N, Loke P, Blaser MJ 2014. Altering the intestinal microbiota during a critical developmental window has lasting metabolic consequences. Cell, 158: 705-721

Cuervo AM 2004. Autophagy: in sickness and health. Trends Cell Biol. 14: 70-77

Cunliffe M, Engel A, Frka S, Gašparović B, Guitart C, Murrell JC, Salter M, Stolle C, Upstill-Goddard R, Wurl O 2013. Sea surface microlayers: a unified physicochemical and biological perspective of the air-ocean interface. Prog. Oceanography 109: 104-116

Dadvand P, de Nazelle A, Figueras F, Basagaña X, Su J, Amoly E, Jerrett M, Vrijheid M, Sunyer J, Nieuwenhuijsen MJ 2012. Green space, health inequality and pregnancy. Environ Int 40:110115

D'amato 2000. Urban air pollution and plant-derived respiratory allergy. Clin. Exp. Allergy 30: 628-636

Dan HC, Cooper MJ, Cogswell PC, Ting JP-Y, Baldwin AS 2008. Akt-dependant regulation of NF-KB is controlled by mTOR and Raptor in association with IKK. Genes \& Dev. 22: 1490-1500 
Davinelli S, Willcox DC, Scapagnini G 2012. Extending healthy ageing: nutrient sensitive pathway and centenarian population. Immun. Ageing 9:9. doi: 10.1186/1742-4933-9-9

de las Heras B, Hortelano S 2009. Molecular basis of the anti-imflammatory effects of terpenoids. Inflamm. Allergy Drug Targets 8: 28-39

de Magalhães JP, Wuttke D, Wood SH, Plank M, Vora C 2011. Genome-environment interactions that modulate aging: powerful targets for drug discovery. Pharmacol. Rev. 64: 88-101

De Martino MC, van Koetsveld PM, Feelders RA, Sprij-Mooij D, Waaijers M, Lamberts SW, de Herder WW, Colao A, Pivonello R, Hofland LJ 2012. The role of mTOR inhibitors in the inhibition of growth and cortisol secretion in human adrenocortical carcinoma cells. Endocrine-related cancer 19:351-364

de Oliveira CB, Comunello LN, Maciel ES, Giubel SR, Bruno AN, Chiela ECF, Lenz G, Gnoatto SCB, Buffon A, Gosmann G 2013. The inhibitory effects of phenolic and terpenoid compounds from Baccharis trimera in Siha cells: differences in their activity and mechanism of action. Molecules 18: $11022-11032$

de Souza ECL, Padrón AS, Braga WMO, de Andrde BM, Vasiman M, Nasciutti LE, Ferreira ACF, de Carvalho DP 2010. mTOR down-regulates iodide uptake in thyrocytes. J. Endocrinol. 206: 113120

Deeb D, Gao X, Dulchavsky SA, Gautam S 2007. CDDO-Me induces apoptosis and inhibits Akt, mTOR and NF-kB signaling proteins in prostate cancer cells. Anticancer Res. 27: 3035-3044

Delmas D, Solary E, Latruffe N 2011. Resveratrol, a phytochemical inducer of multiple cell death pathways: apoptosis, autophagy and mitotic catastrophe. Curr. Med. Chem. 18: 1100-1121

Del Rio D, Rodriguez-Mateos A, Spencer JP, Tognolini M, Borges G, Crozier A 2013. Dietary (poly) phenolics in human health: structures, bioavailability, and evidence of protective effects against chronic diseases. Antiox. Redox Signal. 18: 1818-1892

Depledge MH, Harvey AJ, Brownlee C, Frost M, Moore MN, Fleming LE 2013. Changing views of the interconnections between the Oceans and Human Health in Europe. Microbial Ecol. 65: 852-859

Després VR, Huffman JA, Burrows SM, Hoose C, Safatov AS, Buryak G, Fröhlich-Nowoisky J, Elbert W, Andreae MO, Pöschl U, Jaenicke R 2012. Primary biological aerosol particles in the atmosphere: a review. Tellus B, 64: 015598, DOI: 10.3402/tellusb.v64i0.15598

Dreyer HC, Fujita S, Cadenas JG, Chinkes DL, Volpi E, Rasmussen BB 2006. Resistance exercise increases AMPK activity and reduces 4E-BP1 phosphorylation and protein synthesis in human skeletal muscle. J. Physiol. 576: 613-624

Duke SO 2011. Phytochemical phytotoxins and hormesis - a commentary. Dose-Response 9: 76-78

Dungan RS 2011. Airborne endotoxin from indoor and outdoor environments: effect of sample dilution on the kinetic Limulus amebocyte lysate (LAL) assay. J. Occupat. Environ. Hygiene 8: 147-153 
Eskelinen E-L, Saftig P 2009. Autophagy: a lysosomal degradation pathway with a central role in health and disease. Biochim. Biophys. Acta - Mol. Cell Res 1793: 4664-4673

Farmer EA, Ryan CA 1990. Interplant communication: Airborne methyl jasmonate induces synthesis of proteinase inhibitors in plant leaves. Proc. Natl. Acad. Sci. USA 87: 7713-7716

Farrand L, Oh S-W, Song YS, Tsang BK 2014. Phytochemicals: a multitargeted approach to gynecologic cancer therapy. BioMed Res. Internat. 2014: http://dx.doi.org/10.1155/2014/ 890141

Ferrari N, Tosetti F, De Flora S, Donatelli F, Sogno I, Noonan DM, Albini A 2011. Diet-derived phytochemicals: from cancer chemoprevention to cardio-oncological prevention. Curr. Drug Targets 12: 1909-1924

Fischer G, Dott W 2003. Relevance of airborne fungi and their secondary metabolites for environmental occupational and indoor hygiene. Arch. Microbiol. 179: 75-82

Fleming LE, Backer LC, Baden DG 2005. Overview of aerolosized Florida red tide toxins: exposures and effects. Environ. Health Perspect. 113: 618-620.

Fleming LE, Kirkpatrick B, Backer LC, Bean JA, Wanner A, Reich A, Zaias J, Cheng YS, Pierce R, Naar J, Abraham WM, Baden DG 2007. Aerosolized red tide toxins (brevetoxins) and asthma. Chest 131: 187-194

Fleming LE, McDonough N, Austen M, Mee L, Moore M, Hess P, Depledge MH, White M, Philippart K, Bradbrook P, Smalley A 2014. Oceans and Human Health: a rising tide of challenges and opportunities for Europe. Mar. Environ. Res. 99: 16-19

Fontana L, Partridge L, Longo VD 2010. Extending healthy life span - from yeast to humans. Science 328: $321-326$

Frohlich-Nowoisky J, Pickersgill DA, Després VR, Poschl U 2009. High diversity of fungi in air particulate matter. Proc. Nat. Acad. Sci. 106: 12814 - 12819

Frumkin $\mathrm{H}$ 2001. Beyond toxicity: human health and the natural environment. Am. J. Prev. Med. 20: 234-240

Gantar M, Dhandaayuthapani S, Rathinavelu A 2012. Phycocyanin induces apoptosis and enhances the effect of topecan on prostate cell line LNCaP. J. Medicinal Food 15: 1091-1095

Gerriets VA, Rathmell JC 2012. Metabolic pathways in T cell fate and function. Trends Immunol. 33: 168-173

Gerssen A, van Olst EH, Mulder PP, de Boer J 2010. In-house validation of a liquid chromatography tandem mass spectrometry method for the analysis of lipophilic marine toxins in shellfish using matrix-matched calibration. Analyt. Bioanalyt. Chem. 397: 3079-3088

Ghoshal KP, Saoji AA 2013. Phytochemical screening of the pollen of some selected plants with antidiabetic properties. Austral. J. Basic Appl. Sci. 7: 105-109 
Goufo P, Trindade, H 2014. Rice antioxidants: phenolic acids, flavonoids, anthocyanins, proanthocyanidins, tocopherols, tocotrienols, c-oryzanol, and phytic acid. Food Sci. Nutr. 2: 75104

Graham B, Guyon P, Maenhaut W, Taylor PE, Ebert M, Matthias-Maser S, Mayol-Bracero OL, Godoi RHM, Artaxo P, Meixner FX, Moura MAL, Carlos H. Eça D'Almeida Rocha CHED'A, Van Grieken R, Glovsky MM, Flagan RC, Andreae MO 2003. Composition and diurnal variability of the natural Amazonian aerosol. J. Geophys. Res. 108 (D24): 4765, doi:10.1029/2003JD004049

Griffin DW, Donaldson KA, Paul JH, Rose JB 2003. Pathogenic human viruses in coastal waters. Clin. Microbiol. Rev. 16: 129-143

Halliwell B 2009. The wanderings of a free radical. Free Radical Biol. Med. 46: 531-542

Harries LW, Fellows AD, Pilling LC, Hernandez D, Singleton A, Bandinelli S, Guralnik J, Powell J, Ferrucci L, Melzer D 2012. Advancing age is associated with gene expression changes resembling mTOR inhibition: evidence from two human populations. Mech. Ageing Devel. 133: $556-562$

Hau AM, Greenwood JA, Lohr CV, Serrill JD, Proteau PJ, Ganley IG, McPhail KL, Ishmael JE 2013. Coibamide A induces mTOR-independent autophagy and cell death in human glioblastoma cells. PLoS ONE, 8(6): e65250. Doi:10.1371/journal. pone.0065250

Hippert M M, O'Toole P S, Thorburn A 2006. Autophagy in cancer: good, bad, or both? Cancer Res. 66: 9349-9351

Hooper PL, Hooper PL, Tytell M, Vigh L 2010, Xenohormesis: health benefits from an eon of plant stress response evolution. Cell Stress Chaperones 15: 761-770

Huang H-C, Syu K-Y, Lin J-K 2010. Chemical composition of Solanum nigrum Linn extract and induction of autophagy by leaf water extract and its major flavonoids in AU565 breast cancer cells. J. Agric. Food Chem. 58: 8699-8708

Huang R-J, Thorenz UR, Kundel M, Venables DS, Ceburnis D, Ho FF, Chen J, Vogel AL, Küpper FC, Smyth PPA, Nitschke U, Stengel DB, Berresheim H, O'Dowd CD, Hoffmann T 2013. The seaweeds Fucus vesiculosis and Ascophyllum nodosum are significant contributors to coastal iodine emissions. Atmos. Chem. Phys. 13: 5255-5264

Hurd L 2003. Bee pollen: top rank antioxidant. Tot. Health 24: 40-42

Ibañez E, Herrero M, Mendiola JA, Castro-Puyana M 2012. Extraction and characterization of bioactive compounds with health benefits from marine resources: macro and micro algae, cyanobacteria, and invertebrates. In: Marine bioactive compounds: sources, characterization and applications, (Ed. M. Hayes) DOI 10.1007/978-1-4614-1247-2_2, @ Springer Science+Business Media, LLC 2012 
Inglés M, Gambini J, Miguel MG, Bonet-Costa V, Abdelaziz KM, El Alami M, Viña J, Borrás C 2014. PTEN mediates the antioxidant effect of resveratrol at nutritionally relevant concentrations. BioMed. Res. Internat. Article ID 580852, 6 pages. http://dx.doi.org/10.1155/2014/580852

Jeong Y-T, Kim YD, Jung Y-M, Park D-C, Lee D-S, Ku S-K, Li X, Lu Y, Chao GH, Kim K-J, Lee J-Y, Baek M-C, Kang W, Hwang S-L, Chang HW 2013. Low molecular weight fucoidan (LMWF) improves ER stress-reduced insulin sensitivity through AMPK activation in L6 myotubes and restores lipid homeostasis in a mouse model of type 2 diabetes. Mol Pharmacol. 84: 147-57

Johnson SM, Gulhati P, Arrieta I, Wang X, Uchida T, Gao T, Evers, BM 2009. Curcumin inhibits proliferation of colorectal carcinoma by modulating Akt/mTOR signalling. Anticancer Res. 29: $3185-3190$

Jones AM, Harrison RM 2003. The effects of meteorological factors on atmospheric bioaerosol concentrations - a review. Sci. Total Environ. 326: 151-180

Kaur R, Kumar NR, Harjai K 2013. Phytochemical analysis of different extracts of bee pollen. Internat. J. Pharm. Biol. Res. 4: 65-68

Kelsey RG, Stevenson TT, Scholl JP, Watson TJ, Shafizadeh F 1978. The Chemical Composition of the Litter and Soil in a Community of Artemisia tridentata ssp. Vaseyana. Biochem. Systemat. Ecol. 6: 193-200

Kennedy DO, Wightman EL 2011. Herbal extracts and phytochemicals: plant secondary metabolites and the enhancement of human brain function. Adv. Nutr. 2: 32-50

Khan N, Afaq F, Saleem M, Ahmad N, Mukhtar H 2006. Targeting multiple signaling pathways by green tea polyphenol (-)-epigallocatechin-3-gallate. Cancer Res. 66: 2500-2505

Kim MK, Suh DH, Seoung J, Kim HS, Chung HH, Song YS 2012. Autophagy as a target for anticancer therapy and its modulation by phytochemicals. J. Food Drug Anal. 20; (Suppl. 1): 241-245

Kim SJ, Cho AR, Han J 2013. Antioxidant and antimicrobial activities of leafy green vegetable extracts and their applications to meat product preservation. Food Control 29: 112-120

Klionsky DJ et al. 2007. Guidelines for the use and interpretation of assays for monitoring autophagy in higher eukaryotes. Autophagy 4: 1-25.

Kong D, Zhang Y, Yamori T, Duan H, Jin M 2011. Inhibitory activity of flavonoids against Class I phosphatidylinositol 3-kinase isoforms. Molecules 16: 5159-5167

Korsnes MS 2012. Yessotoxin as a tool to study induction of multiple cell death pathways. Toxins 4: 568-579

Kourtchev I, Fuller S, Aalto J, Ruuskanen TM, McLeod MW, Maenhaut W, Jones R, Kulmala M, Kalberer M 2013. Molecular composition of boreal forest aerosol from Hyytiälä, Finland, using ultrahigh resolution mass spectrometry. Environ. Sci. Technol. 47: 4069-4079 
Kraft C, Peter M, Hofmann K 2010. Selective autophagy: ubiquitin-mediated recognition and beyond. Nature Cell Biol. 12: 836-841

Krajcsi P, Wold WSM 1998. Viral proteins that regulate cell signalling. J. Gen. Virol. 79: 1323-1335

Krivácsy Z, Kiss G, Ceburnis D, Jennings G, Maenhaut W, Salma I, \& Shooter D 2008. Study of water-soluble atmospheric humic matter in urban and marine environments. Atmos. Res. 87: 112

Kroll JH, Seinfeld JH 2008. Chemistry of secondary organic aerosol: Formation and evolution of lowvolatility organics in the atmosphere. Atmos. Environ. 42:, 3593-3624

Kuiter AT, Denneman CAJ 1987. Water-soluble phenolic substances in soils under several coniferous and deciduous tree species. Soil Biol. Biochem. 19: 765-76

Kulmala M, Hämeri K, Aalto PP, Mäkelä, JM, Pirjola L, Nilsson ED, Buzorius G, Rannik Ü, Dal Maso M, Seidl W, Hoffmann T, Janson R, Hansson H-C, Viisanen Y, Laaksonen A, O'Dowd CD 2001. Overview of the international project on biogenic aerosol formation in the boreal forest (BIOFOR), Tellus B, 53, 324-343

Kusuhara M, Urakami K, Masuda Y, Zangiacomi V, Ishii H, Tai S, Maruyama K, Yamaguchi K 2012. Fragrant environment with a-pinene decreases tumor growth in mice. Biomed. Res. 33: 57-61

Lamb CA, Yoshimori T, Tooze SA 2013. The autophagosome: origins unknown, biogenesis complex. Nature Rev. Mol. Cell Biol. 14: 759-774

Lamming DW, Ye L, Sabatini DM, Baur JA 2013. Rapalogs and mTOR inhibitors as anti-aging therapeutics. J. Clin. Invest. 123: 980-989

Laplante M, Sabatini DM 2009. mTOR signaling at a glance. J. Cell Sci. 122: 3589-3594

Laplante M, Sabatini DM 2012 mTOR signaling in growth control and disease. Cell 149: 274-293

Lee H, Kim J-S, Kim E 2012. Fucoidan and seaweed Fucus vesiculosis inhibits migration and invasion of human lung cancer cell via PI3K-Akt-mTOR pathways. PLoS ONE 7(11): e50624. doi:10.1371/journal.pone.0050624

Lee P-S, Wilhelmson ASK, Hubner AP, Reynolds SB, Gallachi DA, Chiou TT, Kwiatkowski DJ 2010. mTORC1-S6K activation by endotoxin contributes to cytokine up-regulation and early lethality in animals. PloS ONE 5(12): e14399. Doi: 10.1371/journal. pone.0014399

Levine B, Kroemer G 2008. Autophagy in the pathogenesis of disease. Cell 132: 27-42

Lippmann M, Yeates DB, Albert RE 1980. Deposition, retention, and clearance of inhaled particles. Br. J. Ind. Med. 37: 337-362

Lisse TS, Hewison M 2011. Vitamin D - a new player in the world of mTOR signalling. Cell Cycle 10: 1888-1889 
Maas J, Verheij RA, Groenewegen PP, de Vries S, Spreeuwenberg P 2006. Green space, urbanity, and health: how strong is the relation? J. Epidemiol. Community Health 60: 587-592

Madrid LV, Mayo MW, Renther JY, Baldwin AS Jr (2001. Akt stimulates the transactivation potential of the RelA/p65 subunit of NF-kappaB through utilization of the I kappa B kinase and activation of the mitogen activated protein kinase p38. J. Biol. Chem. 276: 18934-18940

de Magalhães JP, Wuttke D, Wood SH, Plank M, Vora C 2011. Genome-environment interactions that modulate aging: powerful targets for drug discovery. Pharmacol. Rev. 64: 88-101

Malloy CD, Marr JS 1997. Mycotoxins and public health: a review. J. Public Health Manag. Pract. 3: 61-69

Markman B, Dienstmann R, Tabernero J 2010. Targeting the PI3K/Akt/mTOR pathway - beyond rapalogs. Oncotarget 1: 530-543

Martin S, Saha, B, Riley, JL 2012. The battle over mTOR: an emerging theatre in host-pathogen immunity. PLoS Pathog, 8(9): e1002894. Doi:10.1371/journal.ppat.1002894

Martins I, Galluzzi L, Kroemer G 2011. Hormesis, cell death and aging. Aging 3: 821-828

Matricardi PM, Rosmini F, Riondino S, Fortini M, Ferrigno L, Rapicetta M, Bonini S 2000. Exposure to foodborne and orofecal microbes versus airborne viruses in relation to atopy and allergic asthma: epidemiological study. Brit. Med. J. 320: 412-417

Matsunaga SN, Chatani S, Nakatsuka S, Kusumoto D, Kubota K, Utsumi Y, Enoki T, Tani A, Hiura T 2011. Volatile diterpene emission from dominant conifers in Japan. Biogeosci. Disc. 8: 66816700

Matthias-Maser S, Obolkin V, Khodzer T, Jaenicke R 2000. Seasonal variation of primary biological aerosol particles in the remote continental region of Lake Baikal/Siberia. Atmos. Environ. 34:, 3805-3811

Mattson MP 2008. Hormesis defined. Ageing Res. Rev. 7: 1-7

Mattson MP, Wan R 2005. Beneficial effects of intermittent fasting and caloric restriction on the cardiovascular and cerebrovascular systems. J. Nutrit. Biochem. 16: 129-137

Menendez JA, Joven J, Aragonès G, Barrajón-Catalán E, Beltrán-Debón R, Borrás-Linares I, Campos J, Corominas-Faja B, Cufí S, Fernández-Arroyo S, Garcia-Heredia A, Hernández-Aguilera A, Herranz-López M, Jiménez-Sánchez C, López-Bonet E, Lozano-Sánchez J, Luciano-Mateo $F$, Martin-Castillo B, Martin-Paredero V, Pérez-Sánchez A, Oliveras-Ferraros C, Riera-Borrull M, Rodríguez-Gallego E, Quirantes-Piné R, Rull A, Tomás-Menor L, Vazquez-Martin A, AlonsoVillaverde C, Micol V, Segura-Carretero A 2013. Xenohormetic and anti-ageing activity of secoiridoid polyphenols present in extra virgin olive oil. Cell Cycle 12: 555-578

Mestre MB, Colombo MI 2013. Autophagy and toxins: a matter of life or death. Curr Mol Med. 13: $241-251$ 
Mizushima N, Levine B, Cuervo AM, Klionsky DJ 2008. Autophagy fights disease through cellular selfdigestion. Nature 451: 1069-1075

Mitchell R, Popham F 2008. Effect of exposure to natural environment on health inequalities: an observational population study. Lancet 372: 1655-1660

Møller MTN, Samari HR, Seglen PO 2004. Toxin-induced tail phosphorylation of hepatocellular S6 kinase: evidence for a dual involvement of the AMP-activated protein kinase in S6 kinase regulation. Toxicol. Sci. 82: 628-637

Moore MN 2008. Autophagy as a second level protective process in conferring resistance to environmentally-induced oxidative stress. Autophagy 4: 254-256

Moore MN, Stebbing ARD 1976. The quantitative cytochemical effects of three metal ions on a lysosomal hydrolase of a hydroid. J. mar. biol. Assoc. UK 56: 995-1005

Moore MN, Depledge MH, Fleming L, Hess P, Lees D, Leonard P, Madsen L, Owen R, Pirlet H, Seys, $\mathrm{J}$, Vasconcelos V, Viarengo A 2013. Oceans and human health (OHH): a European perspective from the Marine Board of the European Science Foundation (Marine Board-ESF). Microbial Ecol. 65: 889-900

Moore MN, Depledge MH, Fleming L, Hess P, Lees D, Leonard P, Madsen L, Owen R, Pirlet H, Seys J, Vasconcelos V, Viarengo A 2014. Linking oceans \& human health: a strategic research priority for Europe. Position Paper 19. European Marine Board, Ostend, Belgium, 111p

Moore MN, Koehler A, Lowe D, Viarengo A 2008. Lysosomes and autophagy in aquatic animals. In: Methods in Enzymology (D.Klionsky, Ed), vol. 451: 582-620. Academic Press/Elsevier, Burlington.

Moore MN, Viarengo A, Donkin P, Hawkins AJS 2007. Autophagic and lysosomal reactions to stress in the hepatopancreas of blue mussels. Aquatic Toxicol. 84: 80-91.

Munday R (2013). Is protein phosphatase inhibition responsible for the toxic effects of okadaic acid in animals. Toxins 5: 267-285

Murakami A 2013. Modulation of protein quality control systems by food phytochemicals. J. Clin. Biochem. Nutr. 52: 215-227

Nacarelli T, Azar A, Sell C 2014. Inhibition of mTOR prevents ROS production initiated by ethidium bromide-induced mitochondrial DNA depletion. Front. Endocrinol. 5: 122-130

Nagle DG, Zhou Y-D 2009. Marine natural products as inhibitors of hypoxic signalling in tumors. Phytochem. Rev. 8: 415-429

Nam NH 2006. Naturally occurring NF-kappaB inhibitors. Mini Rev. Med. Chem., 6: 945-951

O'Dowd CD, de Leeuw G 2007. Marine aerosol production: a review of the current knowledge. Phil. Trans. Roy. Soc. A 365: 1753-1774 
Okuda M, Ohkubo K, Gotoh M, Hiroshima K, IshidaY, Hori K 2005. Dynamics of airborne pollen particles from inhalation to allergic reaction in the nose. Rhinology 43: 29-33

Ong T, Wong W-Z, Stewart JD, Brockman HE 1986. Chlorophyllin: a potent antimutagen against environmental and dietary complex mixture. Mutat. Res. 173: 111-115

Ong T, Brockman HE, Whong W-Z 1994. Chlorophyllin: an antigenotoxic agent. Food Phytochemicals for Cancer Prevention Chapter 22, pp 272-281. ACS Symposium Series, Vol. 546

Ozkan A, Sen HM, Sehitoglu I, Alacam H, Guven M, Aras AB, Akman T, Silan C, Cosar M, Karaman HI 2015. Neuroprotective effect of humic acid on focal cerebral ischemia injury: an experimental study in rats. Inflamm. 38: 32-39

Pandey KB, Rizvi SI 2009. Plant polyphenols as dietary antioxidants in human health and disease. Oxid. Med. Cell. Longevity 2: 270-278

Paré PW, Tumlinson JH 1999. Plant volatiles as a defense against insect herbivores. Plant Physiol. 121: $325-332$

Park B-J, Tsunetsugu Y, Kasetani T, Hirano H, Kagawa T, Sato M, Miyazaki Y 2007. Physiological Effects of Shinrin-yoku (Taking in the Atmosphere of the Forest)-Using Salivary Cortisol and Cerebral Activity as Indicators. J. Physiol. Anthropol. 26:123-128

Park B-J, Tsunetsugu Y, Kasetani T, Hirano H, Kagawa T, Sato M, Miyazaki Y 2010a. The physiological effects of Shinrin-yoku (taking in the forest atmosphere or forest bathing): evidence from field experiments in 24 forests across Japan. Environ. Health Prev. Med. 15:18-26

Park HS, Kim SR, Kim JO, Lee YC 2010b. The roles of phytochemicals in bronchial asthma. Molecules, 1510: 6810-6834

Pearce SHS, Cheetham TD 2010. Diagnosis and management of vitamin D deficiency. Brit. Med. J. 340: $142-147$

Pierce RH 1986. Red tide (Ptychodiscus brevis) toxin aerosols: a review. Toxicon, 24: 955-965

Pierce RH, Henry MS, Higham CJ, Blum P, Sengco MR, Anderson DM 2004. Removal of harmful algal cells (Karenia brevis) and toxins from seawater culture by clay flocculation. Harmful Algae 3: $141-148$

Postolache TT, Lapidus M, Sander ER, Langenberg P, Hamilton RG, Soriano JJ, McDonald NF, Jie Bai J, Scrandis DA, Cabassa JA, Stiller JW, Balis T, Guzman A, Togias A, Tonelli LH 2007. Changes in allergy symptoms and depression scores are positively correlated in patients with recurrent mood disorders exposed to seasonal peaks in aeroallergens. Sci. World J. 7: 19681977

Pott F, Stobert W 1983. Carcinogenicity of airborne combustion products observed in subcutaneous tissue and lungs of laboratory rodents. Environ. Health Perspect. 47: 293-303 
Rahman I, Biswas SK, Kirkham PA 2006. Regulation of inflammation and redox signaling by dietary polyphenols. Biochem. Pharmacol. 72: 1439-1452

Ramos S 2008. Cancer chemoprevention and chemotherapy: dietary polyphenols and signalling pathways. Mol. Nutrit. Food Res. 52: 507-526

Reemtsma T, Quintana JB, Rodil R, García-López M, Rodríguez I 2008. Organophosphorus flame retardants and plasticizers in water and air I. Occurrence and fate. TrAC 27: 727-737

Rogge WF, Hildemann LM, Mazurek MA, Cass GR 1993a. Quantification of urban organic aerosols at a molecular level" identification, abundance and seasonal variation. Atmos. Environ. 27A: 13091330

Rogge WF, Hildemann LM, Mazurek MA, Cass GR, Simoneit BRT 1993b. Sources of fine organic aerosol. 3. Road dust, tire debris, and organometallic brake lining dust: roads as sources and sinks. Environ. Sci. Technol. 27: 1892-1904

Rogge WF, Hildemann LM, Mazurek MA, Cass GR, Simoneit BRT 1993c. Sources of fine organic aerosol. 4. Particulate abrasion products from leaf surfaces of urban plants. Environ. Sci. Technol. 27: 2700-2711

Rook GA 2013. Regulation of the immune system by biodiversity from the natural environment: an ecosystem service essential to health. Proc. Nat. Acad. Sci. 110: 18360-18367

Rubinsztein DC, Mariño G, Guido Kroemer G 2011. Autophagy and aging. Cell 146: 682-695

Russell PB, Bergstrom RW, Shinozuka Y, Clarke AD, DeCarlo PF, Jimenez JL, Livingston JM, Redemann J, Dubovik O, Strawa, A. 2010. Absorption Angstrom Exponent in AERONET and related data as an indicator of aerosol composition. Atmos. Chem. Phys. 10: 1155-1169

Russo R, Cassiano MGV, Ciociaro A, Adornetto A, Varano GP, Chiappini C, Berliocchi L, Tassorelli C, Bagetta G, Corasaniti MT 2014. Role of d-limonene in autophagy induced by bergamot essential oil in SH-SY5Y neuroblastoma cells. PloS one 9 e113682. doi:10.1371/ journal.pone. 0113682

Sabatini DM 2006. mTOR and cancer: insights into a complex relationship. Nat. Rev. Cancer 6: 729734

Salminen A, Kaarniranta K 2009a. SIRT1: regulation of longevity via autophagy. Cell. Signal 21: 1356-1360

Salminen A, Kaarniranta K 2009b. NF-KB signalling in the aging process. J. Clin. Immunol. 29: 397405

Salminen A, Kaarniranta K 2010. Genetics vs. entropy: longevity factors suppress the NF-KB-driven entropic aging process. Ageing Res. Rev. 9: 298-314 
Salminen A, Lehtonen M, Suuronen T, Kaarniranta K, Huuskonen J 2008. Terpenoids: natural inhibitors of NF-KB signaling with anti-inflammatory and anti-cancer potential. Cell. Mol. Life Sci. 65: 2979-2999

Salminen A, Hyttinen JMT, Kauppinen A, Kaarniranta K 2012. Context-dependent regulation of autophagy by IKK - NF-KB signaling: impact on the aging process. Int. J. Cell Biol. 2012 Article ID 849541, 15 pages http://dx.doi.org/10.1155/2012/849541

Sandifer PA, Sutton-Grier AE, Ward BP 2015. Exploring connections among nature, biodiversity, ecosystem services, and human health and well-being: Opportunities to enhance health and biodiversity conservation Ecosys. Serv. 12: 1-15

Sarojini, Y, Laksshminarayana, K, Rao, PS 2012. Variations in distribution of flavonoids in some seaweed of Visakhapatnam coast of India. Der Pharma Chemica 4: 1481-1484

SarrafZadegan N, AminiNik S 1997. Blood pressure pattern in urban and rural areas in Isfahan, Iran. J. Human Hyperten. 11: 425-428

Seedorf H, Griffin NW, Ridaura VK, Ridaura VK, Reyes A, Cheng J, Rey FE, Smith MI, Simon GM, Scheffrahn RH, Woebken D, Spormann AM, Van Treuren W, Ursell LK, Pirrung M, RobbinsPianka A, Cantarel BL, Lombard V, Henrissat B, Knight R, Gordon JI 2014. Bacteria from diverse habitats colonise and compete in the mouse gut. Cell 159: 253-266

Selvakumaran M, Amaravadi RK, Vasilevskaya IA, O'Dwyer PJ 2013. Autophagy inhibition sensitizes colon cancer cells to antiangiogenic and cytotoxic therapy. Cancer Res. 19: 2995-3007

Scherz-Shouval R, Elazar Z 2011. Regulation of autophagy by ROS: physiology and pathology. Trends Biochem. Sci. 36: 30-38

Shapiro K, Krusor C, Mazzillo FF, Conrad PA, Largier JL, Mazet JA, Silver MW 2014. Aquatic polymers can drive pathogen transmission in coastal ecosystems. Proc. Roy. Soc. B: Biological Sciences 281(1795): 20141287. doi: 10.1098/rspb.2014.1287

Shelton BG, Kirkland KH, Flanders WD, Morris GK 2002. Profiles of airborne fungi in buildings and outdoor environments in the United States. Appl. Environ. Microbiol. 68: 1743-1753

Skaug MA, Helland I, Solvoll K, Saugstad OD 2001. Presence of ochratoxin A in human milk in relation to dietary intake. Food Add. Contam. 18: 321-327

Smillie CS, Smith MB, Friedman J, Cordero OX, David LA, Alm EJ 2011. Ecology drives a global network of gene exchange connecting the human microbiome. Nature 480: 241-244

Son YS, Lim BA, Park HJ, Kim JC 2013. Characteristics of volatile organic compounds (VOCs) emitted from building materials to improve indoor air quality: focused on natural VOCs. Air Qual. Atmos. Health 6: 737-746

Stanley RG, Linskins HF 1974. Pollen: biology, chemistry and management. Springer-Verlag, Berlin 
Steelman LS, Chappell WH, Abrams SL, Kempf RC, Long J, Laidler P, Mijatovic S, Maksimovic-Ivanic D, Stivala F, Mazzarino MC, Donia M, Fagone P, Malaponte G, Nicoletti F, Libra M, Milella M, Tafuri A, Bonati A, Bäsecke J, Cocco L, Evangelisti C, Martelli AM, Montalto G, Cervello M, McCubrey JA 2011. Roles of the Raf/MEK/ERK and PI3K/PTEN/Akt/mTOR pathways in controlling growth and sensitivity to therapy-implications for cancer and aging. Aging, 3: 192-222

Stegelmeier BL, Edgar JA, Colegate SM, Gardner DR, Schoch TK, Coulombe RA, Molyneux RJ 1999. Pyrrolizidine alkaloid plants, metabolism and toxicity. J. Nat. Toxins 8: 95-116.

Steward GF, Culley Al, Mueller JA, Wood-Charlson EM, Belcaid M, Poisson G 2013. Are we missing half of the viruses in the ocean? ISME J., 7: 672-679

Sundin T, Hentosh P 2012. InTERTesting association between telomerase, mTOR and phytochemicals. Exp. Rev. Mol. Med. 14, e8 doi:10.1017/erm.2012.1

Syed, DN, Adhami, VM, Khan, MI, Mukhtar, H 2013. Inhibition of Akt/mTOR signaling by the dietary flavonoid fisetin. Anti-Cancer Agents Med. Chem., 13: 995-1001

Tan HK, Moad AlH, Tan ML 2014. The mTOR signalling pathway in cancer and the potential mTOR inhibitory activities of natural phytochemicals. Asian Pacific J. Cancer Prev. 15: 6463-6475

Thoppil RJ, Bishayee A 2011. Terpenoids as potential chemoprevetive and therapeutic agents in liver cancer. World J. Hepatol. 27: 228-249

Trocoli A, Djavaheri-Mergny M 2011. The complex interplay between autophagy and NF-kB signalling pathways in cancer cells. Am. J. Cancer Res. 1: 629-649

Tsunetsugu Y, Park BJ, Miyazaki Y 2010. Trends in research related to "Shinrin-yoku" (taking in the forest atmosphere or forest bathing) in Japan. Environ. Health Prev. Med. 15: 27-37

Van Aller GS, Carson JD, Tang W, Peng H, Zhao L, Copeland RA, Tummino PJ, Luo L 2011. Epigallocatechin gallate (EGCG), a major component of green tea, is a dual phosphoinositide-3kinase/mTOR inhibitor. Biochem. Biophys. Res. Commun. 406: 194-199

van Strien RT, Engel R, Holst O, Bufe A, Eder W, Waser M, Braun-Fahrländer C, Riedler J, Nowak D, von Mutius E; ALEX Study Team 2004. Microbial exposure of rural school children, as assessed by levels of $\mathrm{N}$-acetyl-muramic acid in mattress dust, and its association with respiratory health. $\mathrm{J}$. Allergy Clin. Immunol. 113: 860-867

Verrault D, Moineau S, Duchaine C 2008. Methods for sampling airborne viruses. Microbiol. Mol. Biol. Rev. 72: 413-444

von Roemeling CA, Marlow LA, Kennedy WP, Kennedy GT, Copland JA, Menefee ME 2013. Preclinical evaluation of the mTOR inhibitor, temsirolimus, in combination with the epothilone $B$ analog, ixabepilone in renal cell carcinoma. Am. J. Cancer Res. 3: 390-401

Wang DZ 2008. Neurotoxins from marine dinoflagellates: a brief review. Marine Drugs 6: $349-371$ 
Wang P, Liu Z, Liu X, Teng H, Zhang C, Hou L, Zou X 2014 Anti-metastasis effect of fucoidan from Undaria pinnatifida sporophylls in mouse hepatocarcinoma Hca-F cells. PLoS ONE 9(8): e106071. doi: 10.1371/journal.pone.0106071

Wang S, Liu Z, Wang L, Zhang X 2009. NF-KB signalling pathway, inflammation and colorectal cancer. Cell. Mol. Immunol. 6: 327-334

Weijenberg MP, Hughes LA, Bours MJ, Simons CC, van Engeland M, van den Brandt PA 2013. The mTOR pathway and the role of energy balance throughout life in colorectal cancer etiology and prognosis: unravelling mechanisms through a multidimensional molecular epidemiologic approach. Curr. Nutrit. Rep. 2: 19-26

Wheeler BW, White M, Stahl-Timmins W, Depledge MH 2012. Does living by the coast improve health and wellbeing? Health Place 18: 1198-1201

White M, Smith A, Humphryes K, Pahl S, Snelling D, Depledge M 2010. Blue space: the importance of water for preference, affect, and restorativeness ratings of natural and built scenes. J. Environ. Psychol. 30: 482-493

White M, Alcock I, Wheeler BW, Depledge M 2013. Coastal proximity, health and well-being: results from a longitudinal panel survey. Health \& Place 23: 97-103

White MP, Wheeler BW, Herbert S, Alcock I, Depledge MH 2014. Coastal proximity and physical activity: Is the coast an under-appreciated public health resource? Prev. Med. 69: 135-140

Whon TW, Kim M-S, Roh SW, Shin N-R, Lee H-W, Bae J-W 2012. Metagenomic characterization of airborne viral DNA diversity in the near-surface atmosphere. J. Virol. 86: 8211-8231

Wilhelm SW, Suttle CA 1999. Viruses and Nutrient Cycles in the Sea: Viruses play critical roles in the structure and function of aquatic food webs. BioScience 49: 781-788

Williams JV 1963. Inhalation and skin tests with extracts of hay and fungi in patients with farmer's lung. Thorax 18: 182-196

Williamson SJ, Rusch DB, Yooseph S, Halpern AL, Heidelberg KB, Glass JI, Andrews-Pfannkoch C, Fadrosh D, Miller CS, Sutton G, Frazier M, Venter JC 2008. The Sorcerer II global ocean sampling expedition: metagenomic characterization of viruses within aquatic microbial samples. PLoS ONE 23;3(1): e1456. doi: 10.1371/ journal.pone.0001456

Wilson EO 1984. Biophilia. Cambridge, Mass.: Harvard University Press

Womiloju TO, Miller JD, Mayer PM, Brook JR 2003. Methods to determine the biological composition of particulate matter collected from outdoor air. Atmos. Environ. 37: 4335-4344

Wu S, Sun J 2011. Vitamin D, vitamin D receptor, and macroautophagy in Inflammation and infection. Discov Med. 11: 325-335 
Xie H, Lee MH, Zhu F, Reddy K, Huang Z, Kim DJ, Li Y, Peng C, do Lim Y, Kang S, Jung SK, Li X, Li H, Ma W, Lubet RA, Ding J, Bode AM, Dong Z 2013. Discovery of the novel mTOR inhibitor and its antitumor activities in vitro and in vivo. Mol. Cancer Ther. 12: 959-958

Zhang X, Chen LX, Ouyang L, Cheng Y, Liu B 2012. Plant natural compounds: targeting pathways of autophagy as anti-cancer therapeutic agents. Cell Prolif. 45: 466-476.

Zhang Y-J, Duan Y, Zheng XFS 2011. Targeting the mTOR kinase domain: the second generation of mTOR inhibitors. Drug Discov. Today 16: 325-331

Zhou H, Luo Y, Huang S 2010. Updates on mTOR inhibitors. Anticancer Agents Med. Chem. 10: 571 581

\section{Figure Captions}

Fig. 1. Simplified diagram of the multiple cell signalling pathways involving mTOR (see Laplante \& Sabatini, 2009, 2012, for a more extensive chart of mTOR related cell signalling). Overactivity of mTORC1 is believed to trigger inflammatory processes which can result in pathological injury and processes leading to many cancers and degenerative diseases. PI3K -phosphatidylinositol3 kinase; $\mathrm{PIP}_{3}$ - phosphatidylinositol 3,4,5 trisphosphate; Akt - serine/threonine kinase Akt or protein kinase B (PKB); mTORC1 - mammalian target of rapamycin complex 1; NF-KB - nuclear factor kappa-light-chain-enhancer of activated B cells; PTEN - phosphatase and tensin homolog; AMPK - 5' adenosine monophosphate-activated protein kinase p27 - cyclindependent kinase inhibitor; ROS - reactive oxygen species. Activation $\uparrow$; inhibition $\mathrm{T}$.

Fig. 2. Summary diagram of the multiple cellular protective functions of autophagy in normal and diseased cells. Modified from Eskilenin \& Saftig (2009).

Fig. 3. Summary diagram of the psychological, immunoregulation and biogenics explanations for the health benefits accrued from exposure to rural and coastal environments (Green-Blue Space; adapted in part from Rook (2013). * Treg - the regulatory T cells (Treg), formerly known as suppressor $T$ cells, are a subpopula on of $\underline{T \text { cells }}$ which modulate the immune system, maintain tolerance to self-an gens, and abrogate autoimmune disease. 
Table 1. Summary of various types, sources and targets/effects of potential airborne biogenic chemicals that could influence human health if ingested (see references below).

\begin{tabular}{|c|c|c|}
\hline Biogenic product & Origin & $\begin{array}{l}\text { Potential biological } \\
\text { target or effect }\end{array}$ \\
\hline Bacterial toxins & $\begin{array}{l}\text { Soil particles, seawater } \\
\text { aerosols }\end{array}$ & $\begin{array}{l}\text { Inhibition of specific cell } \\
\text { signalling systems (PI3K, } \\
\text { mTORC1) }\end{array}$ \\
\hline Cyanobacterial toxins & $\begin{array}{l}\text { Seawater aerosols, soil } \\
\text { particles }\end{array}$ & $\begin{array}{l}\text { Inhibition of specific cell } \\
\text { signalling systems (PI3K, } \\
\text { mTORC1) }\end{array}$ \\
\hline Antibiotics & Soil particles & $\begin{array}{l}\text { Inhibition of specific cell } \\
\text { signalling systems (PI3K, } \\
\text { mTORC1) }\end{array}$ \\
\hline $\begin{array}{l}\text { Polyphenolics (flavonoids, } \\
\text { anthocyanins, procyanidins, } \\
\text { proanthocyanidins, catechins, } \\
\text { tannins, humics, etc.) }\end{array}$ & $\begin{array}{l}\text { Soil particles, higher plant } \\
\text { abrasion particles, pollen } \\
\text { grains, fern spores, fungal } \\
\text { spores, macroalgal fragments } \\
\text { (brown, green \& red) }\end{array}$ & $\begin{array}{l}\text { Inhibition of specific cell } \\
\text { signalling systems (PI3K, Akt, } \\
\text { mTORC1), PTEN, MAPK/ERK } \\
\text { (related to cancer), COX-2, } \\
\text { AMPK autophagy, apoptosis, } \\
\text { anti-cancer properties, } \\
\text { cardiovascular protection, } \\
\text { enhanced brain function }\end{array}$ \\
\hline Mycotoxins & $\begin{array}{l}\text { Fungal spores, soil particles, } \\
\text { hay-derived particles }\end{array}$ & $\begin{array}{l}\text { Inhibition of specific cell } \\
\text { signalling systems (PI3K, } \\
\text { mTORC1) }\end{array}$ \\
\hline Pyrrolizidine alkaloids & $\begin{array}{l}\text { Higher plant abrasion } \\
\text { particles, pollen grains }\end{array}$ & $\begin{array}{l}\text { Carcinogenic, tumorigenic \& } \\
\text { anti-cancer properties }\end{array}$ \\
\hline $\begin{array}{l}\text { Terpenoids (monoterpenes, } \\
\text { diterpenes, triterpenes) }\end{array}$ & Higher plants (volatiles) & Apoptosis, autophagy, others \\
\hline $\begin{array}{l}\text { Viral particles or protein } \\
\text { fragments }\end{array}$ & $\begin{array}{l}\text { Marine viruses in airborne } \\
\text { aerosols }\end{array}$ & $\begin{array}{l}\text { Immune system, inhibition or } \\
\text { activation of PI3K, mTORC1, } \\
\text { mTORC2 }\end{array}$ \\
\hline
\end{tabular}


Table 1 References: - Abrahams, 2002; Al-awar et al., 2004; Arafa et al., 2011; Ballou \& Lin, 2008; Banerjee et al., 2014; Beevers et al., 2013; Bennick, 2002; Bharate et al., 2012, 2013; Bode \& Dong, 2013; Boopathy \& Kathiresan, 2010; Buchkovich et al., 2008; Campos et al., 2008; Chai et al., 2012; Chen et al., 2014; Cheng et al., 2005a, b, 2007; Christensen et al., 1999; Cock, 2013; de las Heras \& Hortelano, 2009; Del Rio et al., 2013; de Oliveira et al., 2013; Delmas et al., 2011; Després et al., 2012; Duke, 2011; Farmer \& Ryan, 1990; Farrand et al., 2014; Ferrari et al., 2011; Fischer \& Dott, 2003; Fleming et al., 2005; Fleming et al., 2007, 2014; FrohlichNowoisky et al., 2009; Gantar et al., 2012; Ghoshal \& Saoji, 2013; Goufo \& Trindade, 2014; Hooper et al., 2010; Huang et al., 2013; Hurd, 2013; Ibañez et al., 2012; Inglés et al., 2014; Jeong et al., 2013; Johnson et al., 2009; Kaur et al., 2013; Kelsey et al., 1978; Kennedy \& Wightman, 2011; Kong et al., 2011; Korsnes, 2012; Kourtchev et al., 2013; Krajcsi \& Wold, 1998; Kuiter \& Denneman, 1987; Kusuhara et al., 2012; Lamming et al., 2013; Lee et al., 2012; Lee et al., 2010; Malloy \& Marr, 1997; Matricardi et al., 2000; Matsunaga et al., 2011; Mitchell \& Popham, 2008; Møller et al., 2004; Moore et al., 2013, 2014; Munday, 2013; Murakami, 2013; Nagle \& Zhou, 2009; Nam, 2006; Okuda et al., 2005; Ozkan et al 2015; Pandey \& Rizvi, 2009; Park et al., 2010b; Postolache et al., 2007; Rogge et al., 1993c; Rook, 2014; Russo et al., 2014; Salminen et al., 2008; Sarojini et al., 2012; Shelton et al., 2002; Son et al., 2013; Stegelmeier et al., 1999; Sundin \& Hentosh, 2012; Syed et al., 2013; Tan et al., 2014; Thoppil \& Bishayee, 2011; Tsunetsugu et al., 2010; Van Aller et al., 2011; Wang, 2008; Wang et al., 2014; Williams, 1963; Womiloju et al., 2003; Xie et al., 2013; Zhang et al., 2012; Zhou et al., 2010. 


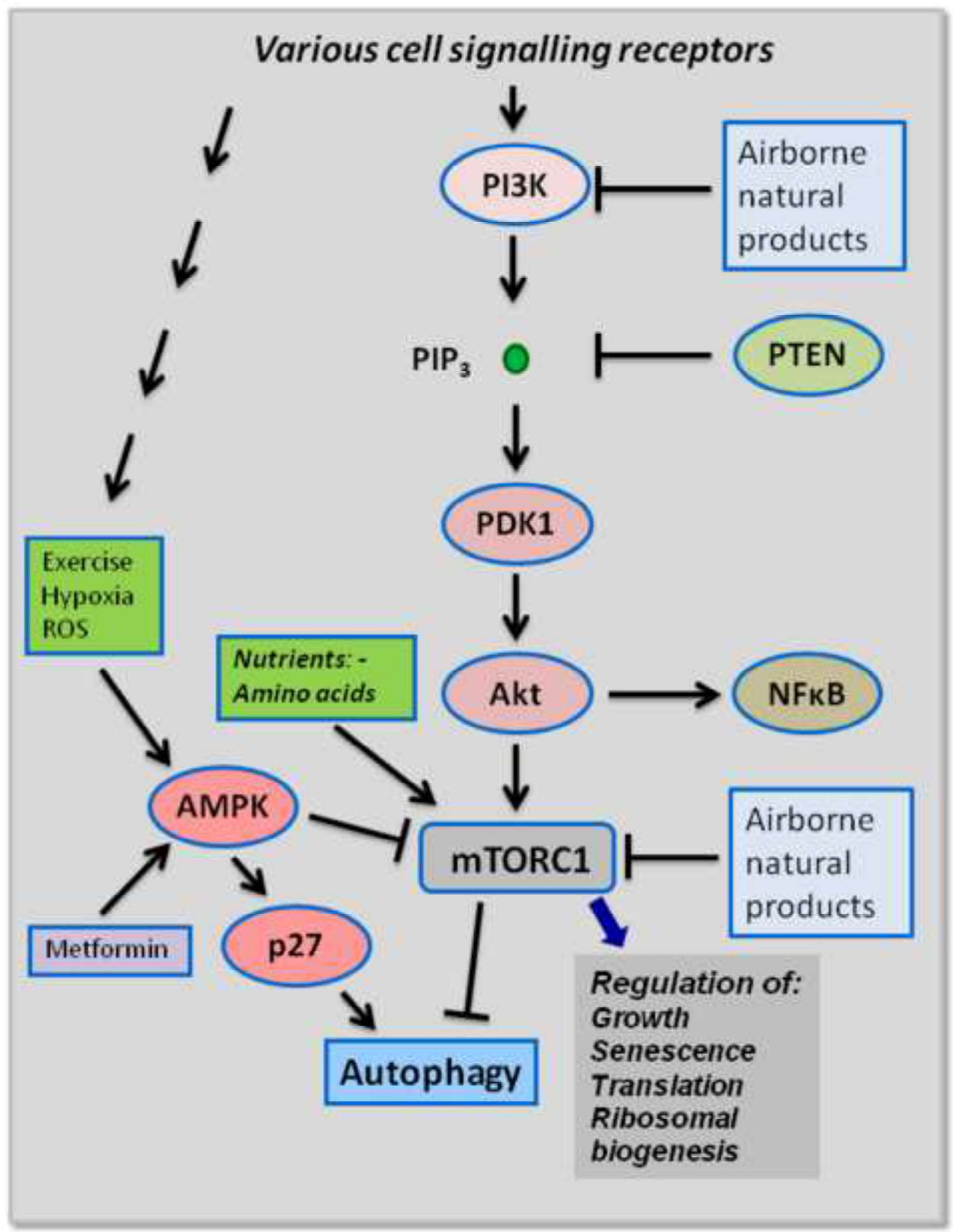

Figure 1 


\section{Major physiological functions of autophagy}

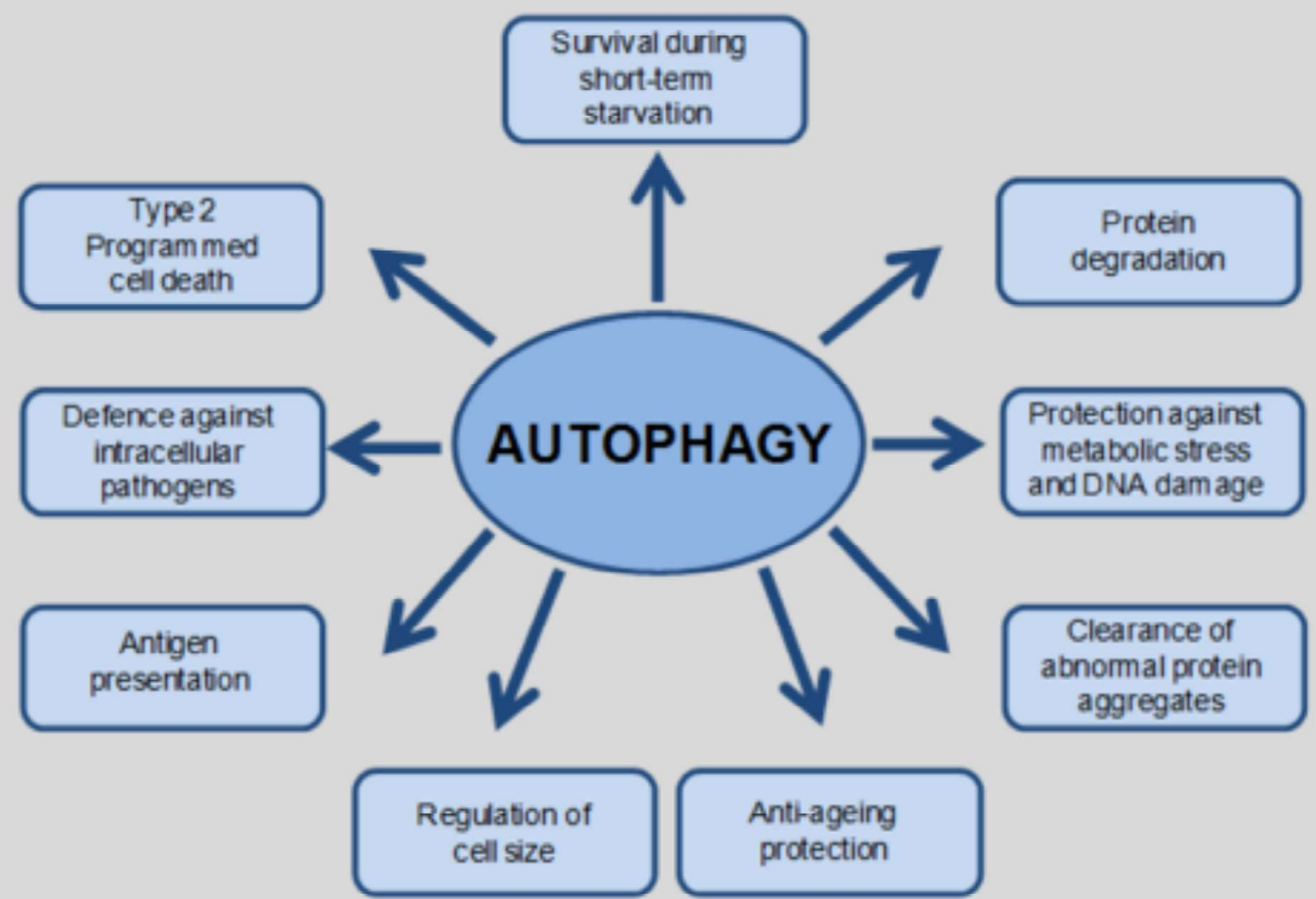

Figure 2 


\begin{tabular}{|c|c|c|c|}
\hline $\begin{array}{l}\text { GREEN-BLUE } \\
\text { SPACE effect }\end{array}$ & $\begin{array}{l}\text { Psychological } \\
\text { Hypothesis }\end{array}$ & $\begin{array}{c}\text { Immunoregulation } \\
\text { Hypothesis }\end{array}$ & $\begin{array}{l}\text { Biogenics } \\
\text { Hypothesis }\end{array}$ \\
\hline $\begin{array}{l}\text { Walking and } \\
\text { recreation in green- } \\
\text { blue space }\end{array}$ & $\begin{array}{l}\text { Evolutionarily } \\
\text { determined } \\
\text { psychological need } \\
\text { (habitat selection?) }\end{array}$ & $\begin{array}{l}\text { Evolutionarily } \\
\text { determined need for } \\
\text { diverse microbial input } \\
\text { to immune system }\end{array}$ & $\begin{array}{l}\text { Evolutionanly } \\
\text { determined need for } \\
\text { diverse exposure to } \\
\text { biogenics }\end{array}$ \\
\hline Social interactions & Build social capital & Exchange of microbiota & $\begin{array}{l}\text { Exchange of } \\
\text { microbiota-associated } \\
\text { biogenics }\end{array}$ \\
\hline Sport \& exercise & $\begin{array}{l}\text { "Hunter-gatherer } \\
\text { ac tivity, heaith benefit. } \\
\text { weight loss }\end{array}$ & $\begin{array}{l}\text { Exchange of } \\
\text { microbicta; more Treg: } \\
\text { immunoreguiation. }\end{array}$ & $\begin{array}{l}\text { Exchange of } \\
\text { microbiota-associated } \\
\text { biogenics, increased } \\
\text { inhalation/ingestion of } \\
\text { biogenics, hypoxia anc } \\
\text { ROS induced mTOR- } \\
\text { inhibition mediated } \\
\text { autophagy }\end{array}$ \\
\hline Sunlight & $\begin{array}{l}\text { Combat Seasonal } \\
\text { Affective Disorder } \\
\text { (SAD) }\end{array}$ & $\begin{array}{l}\text { Vitamin } D \text { and nitnc } \\
\text { oxide (NO) improve } \\
\text { immunoregutation }\end{array}$ & $\begin{array}{l}\text { Enhanced vitamin D: } \\
\text { vitamin D receptor } \\
\text { (VDR) induced } \\
\text { autophagy }\end{array}$ \\
\hline $\begin{array}{l}\text { CLINICAL } \\
\text { OUTCOME }\end{array}$ & & & \\
\hline $\begin{array}{l}\text { Fewer deaths, less } \\
\text { cardiovascular } \\
\text { disease, less } \\
\text { neurodegeneration, } \\
\text { less cancers? } \\
\text { increased longevity? }\end{array}$ & $\begin{array}{l}\text { Relaxation and } \\
\text { exercise? }\end{array}$ & $\begin{array}{l}\text { Low CRP: low } \\
\text { inflamation }\end{array}$ & $\begin{array}{l}\text { Inhibition of } \\
\text { PI3K/Ak/m TOR: } \\
\text { activation of PTEN: } \\
\text { reduced ROS: } \\
\text { enhanced celluiar } \\
\text { housekeeping } \\
\text { (autophagy); improved } \\
\text { innate immunity. Treg' } \\
\text { immunoregulation; low } \\
\text { inflammation: } \\
\text { enhanced brain } \\
\text { function, anti-cancer, } \\
\text { antl-ageing effects: } \\
\text { more stress resilience }\end{array}$ \\
\hline Less depression & $\begin{array}{l}\text { Relaxation, restoration: } \\
\text { social capital? }\end{array}$ & $\begin{array}{l}\text { Lower cytokine } \\
\text { response to stress; } \\
\text { more stress resilience }\end{array}$ & $\begin{array}{l}\text { Inhibition of } \\
\text { PI3K/Akt/mTOR: low } \\
\text { inflammation, more } \\
\text { stress resilience }\end{array}$ \\
\hline
\end{tabular}

Figure 3 
moore_figures-high quality.ppt

Click here to download Supplementary Material: Moore_Figures-high quality.ppt 